\title{
Hubungan Antara Kompetensi, Beban Kerja, Dan Masa Kerja Dengan Waktu Tanggap Perawat Di Instalasi Gawat Darurat Rumah Sakit Medirossa Cikarang
}

\author{
Arry Nurzaman, Cicilia Windiyaningsih, Sonya Dewi Wulandari \\ Universitas Respati Indonesia \\ arrynurzaman@gmail.com
}

\begin{abstract}
Abstrak
Pendahuluan, Waktu tanggap merupakan indikator keberhasilan menangani pasien instalasi gawat darurat (IGD). Kecepatan dan ketepatan dalam menangani pasien gawat darurat sangat dipengaruhi oleh berbagai faktor. Tujuan penelitian yaitu mengetahui hubungan antara kompetensi, beban kerja, dan masa kerja perawat di IGD RS. Medirossa Cikarang, serta faktor mana yang paling dominan mempengaruhi waktu tanggap. Penelitian ini menggunakan metode cross sectional dengan jumlah sampel sebanyak 21 orang. Hasil penelitian terdapat hubungan yang bermakna beban kerja ( $p=0,004, r=0,595)$, dan masa kerja $(p=0,008, r=0,563)$ dengan waktu tanggap perawat di IGD RS. Medirossa Cikarang. Faktor yang paling dominan yang berpengaruh terhadap waktu tanggap yaitu beban kerja. Kesimpulan Perawat di IGD RS. Medirossa Cikarang sebagian besar memiliki waktu tanggap cepat, dimana faktor yang mempengaruhi waktu tanggap yaitu beban kerja. Saran kepada Rumah Sakit agar dapat memberikan pelatihan, meningkatkan fasiltas dan sarana, serta mengadakan forum diskusi terbuka untuk perawat di IGD.
\end{abstract}

Kata kunci : Waktu Tanggap, Kompetensi, Beban Kerja, Masa kerja

\begin{abstract}
Introduction, response time is an indicator of success in treating patients in emergency room. The speed and accuracy in treating patients in emergency room is greatly influenced by various factors. The aim of this study to know the relationship of competence, work load and length of service with nurse respon time in emergency room at Medirossa hospital Cikarang. This study is using cross sectional method with total sample of 21 people. The results of the study have a significant relationship with workload $(p=0.004$, $r=0.595)$ and length of service ( $p=0.008, r=0.563)$ with the respon time of nurses in the emergency room at the Medirossa Hospital Cikarang. Conclussion, Nurses in emergency room at the Medirossa Hospital Cikarang has a fast response time, The factor that affects the response time is workload.
\end{abstract}

Key words : Response Time, Competence, Workload, length of service

\section{PENDAHULUAN}

Instalasi Gawat Darurat (IGD) merupakan unit rumah sakit yang memberikan perawatan pertama kepada pasien. Unit tersebut dipimpan oleh dokter jaga dan tenaga dokter ahli yang berpengalaman dalam menangani pelayanan gawat darurat yang kemudian bila dibutuhkan akan merujuk pasien kepada dokter spesialis tertentu. ${ }^{1}$

Salah satu indikator keberhasilan penanggulangan medik penderita gawat darurat adalah kecepatan memberikan pertolongan yang

http://ejournal.urindo.ac.id/index.php/MARSI memadai kepada penderita gawat darurat baik pada keadaan rutin sehari-hari atau sewaktu bencana. ${ }^{2}$

Waktu tanggap merupakan waktu emas terhadap kehidupan seorang pasien, kegagalan response time di IGD dapat diamati dari yang berakibat fatal berupa kematian atau cacat permanen. ${ }^{3}$ Penelitian yang dilakukan oleh Said dkk (2018) di IGD Rumah Sakit Ibnu Sina Makassar didapatkan waktu tanggap sangat tanggap $61,9 \%$ dan cukup tanggap $38,1 \%$. Pada studi terdahulu didapatkan faktor-faktor yang mempengaruhi waktu tanggap perawat yaitu ketersedian petugas triage, pola penempatan staf, pengetahuan, 
ketrampilan, pengalaman staf, tingkat karateristik pasien, beban kerja, dan masa kerja. ${ }^{5,6,7}$

Berdasarkan hasil observasi di IGD Rumah Sakit (RS) Medirossa Cikarang didapatkan bahwa dalam penanganan pasien sudah menggunakan SOP (Standar Operasional Prosedur) untuk setiap tindakan, namun terkait standar minimal ataupun maksimal waktu tanggap dalam setiap tindakan perawat terhadap pasien yang datang sekitar 30\% masih mendapatkan pelayanan yang kurang tanggap.

Meskipun penelitian tentang waktu tanggap pelayanan IGD telah dilakukan di berbagai negara, namun masih adanya perbedaan waktu tanggap di berbagai rumah sakit di Indonesia. Selain itu belum adanya data mengenai hubungan kompetensi, beban dan masa kerja dengan waktu tanggap perawat di daerah Bekasi. Oleh karena itu, penulis ingin melakukan penelitian tentang "hubungan antara kompetensi kerja, beban kerja dan masa kerja dengan waktu tanggap perawat di instalasi gawat darurat Rumah Sakit Medirossa Cikarang tahun 2021".

\section{METODE}

Penelitian ini menggunakan desain cross sectional. Tempat penelitian dilakukan di IGD RS Medirossa Cikarang. Penelitian ini dilakukan mulai 9 Maret sampai dengan 15 Maret 2021. Populasi dalam penelitian ini adalah seluruh perawat yang bertugas di IGD RS.Medirossa Cikarang.

Tehnik sampel yang digunakan total sampling dengan jumlah sampel yang sebanyak 21 sampel, dengan kriteria inklusi bersedia menjadi responden, perawat yang bertugas di IGD dan kriteria eksklusinya adalah perawat yang pindah dinas, mengundurkan diri, sakit dan tidak bisa melanjutkan proses penelitian. Instrumen yang digunakan adalah lembar observasi dan kuesioner.

Data analisis dengan memnggunakan sistem komputerisasi, yaitu Software Statictic Program For Social Science (SPSS) versi 22 dengan menggunakan uji oneway Anova untuk melihat perbedaan nilai rerata antar variabel, uji pearson dengan tingkat kemaknaan $95 \%(0,05)$ untuk melihat korelasi antar variabel, dan regresi linear berganda untuk melihar pengaruh antar variabel.

\section{HASIL}

Tabel 1. Karateristik Responden

\begin{tabular}{lc}
\hline \multicolumn{1}{c}{ Karateristik } & $\begin{array}{c}\text { Keseluruhan } \\
\mathrm{n}=21\end{array}$ \\
\hline Usia, rerata \pm SD (tahun) & $29,90(3,78)$ \\
Jenis Kelamin, $\mathrm{n}(\%)$ & \\
Laki-laki & $7933,3)$ \\
Perempuan & $14(66,7)$ \\
Pendidikan Terakhir, $\mathrm{n}(\%)$ & \\
D-III Keperawatan & $19(90,5)$ \\
S1- Keperawatan & $2(9,5)$ \\
Masa Kerja, $\mathrm{n}(\%)$ & \\
1-3 tahun & $17(81,0)$ \\
$>3$ tahun & $4(19,0)$ \\
Kompetensi teknis, $\mathrm{n}(\%)$ & \\
Baik & $2(9,5)$ \\
Cukup & $15(71,4)$ \\
Kurang & $4(19,0)$ \\
Kompetensi konseptual, $\mathrm{n}(\%)$ & \\
Baik & $2(9,5)$ \\
Cukup & $13(61,9)$ \\
Kurang & $6(28,6)$ \\
Beban kerja, $\mathrm{n}(\%)$ & \\
Tinggi & $7(33,3)$ \\
Sedang & $8(38,1)$ \\
Rendah & $6(28,6)$ \\
Waktu tanggap , $\mathrm{n}(\%)$ & \\
Cepat & $14(66,7)$ \\
Lambat & $7(33,3)$ \\
\hline
\end{tabular}

Pada penelitian ini juga didapatkan karateristik responden dengan rerata usia 29,90 tahun, jenis kelamin terbanyak perempuan $66,7 \%$, pendidikan terakhir terbanyak D-III keperawatan 90,5\%. Hal ini sejalan dengan penelitian Puspitasari dkk (2015) didapatkan sebangian responden berpendidikan D3 Keperawatan yaitu 66,7\%. Pada penelitian Ningsih dkk (2018) juga didapatkan pendidikan perawat yang terbanyak pada Diploma III Keperawatan sebanyak 82,6\%. 
Karateristik responden berdasarkan masa kerja terbanyak yaitu 1-3 tahun yaitu $81,0 \%$. Hal ini tidak sejalan dengan penelitian Ningsih dkk (2018) yaitu masa kerja perawat terbanyak pada masa kerja lebih 5 tahun sebanyak 56,5\%.

Karateristik responden berdasarkan kompetensi teknis terbanyak yaitu pada kompetensi teknis cukup yaitu $71,4 \%$. Penelitian ini sejalan dengan Ayu (2016), didapatkan kompetensi teknis baik $36,7 \%$ cukup $50,0 \%$, dan kurang $13,3 \%$.

Karateristik responden dengan kompetensi konseptual terbanyak yaitu kelompok dengan kompetensi konseptual cukup sebanyak 61,9\%. Hal ini sejalan dengan penelitian Ayu (2016), didapatkan terbanyak komoetensi cukup 46,7\%, diikuti dengan Baik 33,3\% dan kurang 20,0\%.

Pada karateristik responden dengan beban kerja terbanyak didapatkan pada beban kerja sedang sebanyak 38,1\%. Hal ini tidak sejalan dengan penelitian Junidar (2019) didapatkan beban kerja terbanyak yaitu beban kerja berat sebanyak 51,7\%. Pada penelitian Ningsih dkk (2018) juga didapatkan beban kerja berat sebanyak $56,5 \%$ dan tidak berat sebanyak $43,5 \%$.

Karateristik responden dengan waktu tanggap perawat di IGD didapatkan waktu tanggap cepat $66,7 \%$ dan lambat $33,3 \%$. Hal ini sejalan dengan penelitian Kambuaya dkk (2016) juga didapatkan waktu tanggap baik sebanyak $58 \%$ dan kurang baik $42 \%$.

Tabel 2. Deskriptif oneway Anova

\begin{tabular}{|c|c|c|c|}
\hline $\begin{array}{l}\text { Variabel } \\
\text { bebas }\end{array}$ & $\begin{array}{c}\text { Variabel } \\
\text { terikat }\end{array}$ & Mean ( $\pm S D)$ & Nilai p \\
\hline Kompetensi & Waktu & $35.57(6.925)$ & \\
\hline Teknis & $\begin{array}{l}\text { tanggap } \\
\text { cepat }\end{array}$ & & 0.633 \\
\hline
\end{tabular}

\begin{tabular}{|c|c|c|c|}
\hline & $\begin{array}{l}\text { Waktu } \\
\text { tanggap } \\
\text { lambat }\end{array}$ & $36.93(5.595)$ & \\
\hline \multirow{5}{*}{$\begin{array}{l}\text { Kompetensi } \\
\text { Konseptual }\end{array}$} & Waktu & 24.71(4.751) & \multirow{5}{*}{1.000} \\
\hline & tanggap & & \\
\hline & cepat & & \\
\hline & $\begin{array}{l}\text { Waktu } \\
\text { tanggap }\end{array}$ & 24.71(4.340) & \\
\hline & lambat & & \\
\hline \multirow[t]{5}{*}{ Masa Kerja } & $\begin{array}{l}\text { Waktu } \\
\text { tanggap }\end{array}$ & $34.00(7.416)$ & \multirow{5}{*}{0.001} \\
\hline & cepat & & \\
\hline & Waktu & $22.14(6.163)$ & \\
\hline & tanggap & & \\
\hline & lambat & & \\
\hline \multirow[t]{5}{*}{ Beban Kerja } & Waktu & $34.43(5.062)$ & \multirow{5}{*}{0.004} \\
\hline & tanggap & & \\
\hline & What & & \\
\hline & $\begin{array}{l}\text { Waktu } \\
\text { tanggap }\end{array}$ & $26.00(5.738)$ & \\
\hline & lambat & & \\
\hline
\end{tabular}

Berdasarkan hasil uji ANOVA didapatkan perbedaan rerata beban kerja bermakna dengan waktu tanggap cepat dan waktu tanggap lambat $(p=0,004)$. Pada variabel masa kerja juga di dapatkan perbedaan rerata bermakna masa kerja dengan waktu tanggap cepat dan waktu tanggap lambat $(p=0,001)$. Tidak didapatkan perbedaan rerata bermakna antara kompetensi teknis dan kompetensi konseptual dengan waktu tanggap cepat dan lambat (Tabel 2).

Tabel 3. Analisis Hubungan Kompetensi Teknis dengan Waktu Tanggap Perawat di IGD RS. Medirossa Cikarang

\begin{tabular}{lll}
\hline & & Waktu tanggap \\
\hline Kompetensi & $\mathrm{r}$ & 0,001 \\
teknis & & \\
& $\mathrm{p}$ & 0,996 \\
& $\mathrm{n}$ & 21 \\
\hline
\end{tabular}


Pada uji korelasi pearson didapatkan tidak ada hubungan bermakna antara kompetensi teknis dengan waktu tanggap perawat di IGD RS. Medirossa Cikarang dengan korelasi positif. $(p=0,996, r=0,001)$.

Menurut peneliti, tidak terdapatnya hubungan kompetensi teknis dengan waktu tanggap pada penelitian ini karena proporsi reponden yang memiliki kompetensi teknis kurang hanya sedikit yaitu 4 orang (19\%) dan selain itu cakupan kompetensi terlalu luas dapat meliputi pengetahuan, sikap, dan ketrampilan.

Hal ini sesuai yang dikemukakan oleh Asmawi dkk (2017) pentingnya kompetensi

(pengetahuan, sikap, dan ketrampilan untuk menunjang kinerja dalam melakukan triase gawat darurat. Selain itu pengetahuan, variasinya terlalu luas, bisa berkaitan dengan aspek, tipe, kategori, model, tingkatan dan strata pengetahuan. Pada kuesioner yang digunakan pada penelitian ini sebagian besar pertanyaan hanya mencakup mengenai aspek ketrampilan.

Tabel 4. Analisis Hubungan Kompetensi Konseptual dengan Waktu Tanggap Perawat di IGD RS. Medirossa Cikarang

\begin{tabular}{lll}
\hline & & Waktu tanggap \\
\hline $\begin{array}{l}\text { Kompetensi } \\
\text { konseptual }\end{array}$ & & 0,147
\end{tabular}

$\begin{array}{ll}\mathrm{p} & 0,524 \\ \mathrm{n} & 21\end{array}$

n 21

Pada uji korelasi pearson didapatkan tidak ada hubungan bermakna antara kompetensi konseptual dengan waktu tanggap perawat di IGD RS. Medirossa Cikarang dengan korelasi positif $(p=0,524, r=0,147)$.

Menurut peneliti, tidak terdapatnya hubungan kompetensi teknis dengan wantu tanggap perawat karena proporsi responden yang memiliki kompetensi konseptual kurang hanya sedikit yaitu 6 orang $(28,6 \%)$ sehingga uji korelasi menunjukkan tidak adanya hubungan kedua variabel tersebut.
Kompetensi konseptual merupakan kemampuan intelektual, fisik dan hubungan antar manusia yang mendasari perawat dalam melaksanakan asuhan keperawatan. Kompetensi diukur dengan sub variabel

intelektual, fisik dan human relation. ${ }^{13}$

Tabel 5. Analisis Hubungan Kompetensi Beban Kerja dengan Waktu Tanggap Perawat di IGD RS. Medirossa Cikarang

\begin{tabular}{lll}
\hline & & Waktu tanggap \\
\hline Beban Kerja & $r$ & 0,595 \\
& $p$ & 0,004 \\
& $n$ & 21 \\
\hline
\end{tabular}

Hasil analisa statistik menggunakan uji korelasi pearson didapatkan nilai $r=0,595$ dan nilai $p=$ 0,004 yang berarti adanya korelasi yang bermakna anatara beban kerja dengan waktu tanggap pada perawat IGD ( $p<0,005)$, dimana hubungan keduanya menunjukkan arah korelasi yang positif dengan kekuatan korelasi yang sedang

Penelitian ini juga sejalan dengan penelitian Ningsih dkk (2018) yang menunjukkan ada hubungan beban kerja perawat dengan waktu tanggap pelayanan keperawatan berdasarkan kategori triage prioritas 1 di IGD RSUD Ratu Zalecha Martapura.

Hal ini bertentangan dengan penelitian Said dkk (2018) bahwa tidak ada hubungan yang bermakna antara beban kerja perawat dengan response time perawat. beban kerja yang berat bukan faktor utama yang mempengaruhi ketepatan waktu tanggap, akan tetapi pengetahuan dan pengalaman kerja yang dimiliki perawat dalam menghadapi pasien juga merupakan faktor pendukung dalam ketepatan waktu tanggap hal lain juga yang mempengaruhi ialah karakteristik pasien, tersedianya tempat tidur di dalam IGD dan waktu kedatangnya pasien secara bersamaan.

Menurut peneliti, beban kerja berhubungan dengan waktu tanggap pada penelitian ini yaitu beban kerja fisik. Setiap perawat di IGD dituntut untuk memberikan pelayanan yang berkualitas, 
hal ini dapat menimbulkan stressor kepada perawat. Pasien yang datang ke IGD memiliki kondisi yang berbeda-beda terutama pada pasien dengan kondisi kritis membutuhkan waktu penanganan yang lebih lama. Selain itu, waktu kedatangan pasien sering terjadi bersamaan, hal ini membuat jumlah perawat yang ada tidak sesuai dengan jumlah pasien. Oleh karena stressor tersebut dapat menurukan kecepatan waktu tanggap perawat dalam memberikan pelayanan keperawatan kegawatdaruratan.

Beban kerja perawat dirumah sakit meliputi beban kerja fisik, dan beban kerja mental. Beban kerja fisik seperti mengangkat pasien, memasang infus, melakukan observasi, tandatanda vital, memasang oksigen dan lain-lain. Sedangkan beban kerja yang bersifat mental berupa kompleksitas pekerjaan, mempersiapkan mental dan rohani pasien dan keluarga terutama yang akan menjalankan operasi atau dalam keadaan kritis, bekerja dalam ketrampilan khusus dalam merawat pasien, serta menjalin komunikasi yang baik dengan pasien dan keluarga. ${ }^{14}$

Tabel 6. Analisis Hubungan Masa Kerja dengan Waktu Tanggap Perawat di IGD RS. Medirossa Cikarang

\begin{tabular}{lll}
\hline & & Waktu tanggap \\
\hline Masa Kerja & $\mathrm{r}$ & 0,563 \\
& $\mathrm{p}$ & 0,008 \\
& $\mathrm{n}$ & 21 \\
\hline
\end{tabular}

Hasil analisa statistik menggunakan uji korelasi pearson didapatkan nilai $r=0,563$ dan nilai $p=$ 0,008 yang berarti adanya korelasi yang bermakna anatara masa kerja dengan waktu tanggap pada perawat IGD ( $p<0,005)$, dimana hubungan keduanya menunjukkan arah korelasi yang positif dengan kekuatan korelasi yang sedang
Hal ini sejalan dengan penelitian Wiyadi dkk (2020) didapatkan ada hubungan masa kerja dengan waktu tanggap perawat di IGD RSUD A.Wahab Sjahranie Samarinda. Semakin lama bekerja maka tingkat ketrampilan semakin meningkat atau mahir.

Menurut peneliti, masa kerja perawat sangat berhubungan dengan pengalaman yang dimiliki, sedangkan pada perawat yang baru lulus membutuhkan pengalaman dan pelatihan yang lebih banyak untuk menangani kasus-kasus kegawatdaruratan, dimana pasien dengan kategori triage merah membutuhkan pertolongan medis segera dan waktu tanggap yang cepat.

Tabel 7. Variabel Dominan

\begin{tabular}{llll}
\hline Model & Beta & $\mathrm{t}$ & Sig. \\
\hline Constant & &,- 204 &, 841 \\
Beban kerja &, 439 & 2,361 &, 030 \\
Masa Kerja &, 386 & 2,075 &, 053 \\
\hline
\end{tabular}

Berdasarkan tabel diatas, terlihat pada kolom standardizer coefficients Sehingga dapat disimpulkan bahwa variabel beban kerja memiliki nilai Beta yang lebih besar $(0,439)$ dan nilai $p<$ $0,05(p=0,30)$ dari pada variabel masa kerja, sehingga varibel yang lebih dominan berpengaruh terhadap waktu tanggap yaitu beban kerja.

Aktivitas kerja fisik yang melampaui kapasitas seorang perawat dapat menurunkan produktivitasnya dalam bekerja sehingga hal-hal yang harusnya dilakukan untuk menjaga keselamatan pasien sering dilakukan namun tidak sesuai dengan prosedur yang berlaku. ${ }^{14}$

Perawat di IGD memiliki beban kerja yang sangat tinggi dibandingkan perawat yang ada di bangsal maupun poliklinik. Beban kerja yang terlalu tinggi akan dapat mempengaruhi keandalan perawat dalam melaksanakan pekerjaan. Beban kerja yang dihadapi oleh perawat IGD tergolong berat dikarenakan perawat mengalami tekanan dan tuntutan untuk menyelamatkan pasien baik tuntutan moril, tuntutan pimpinan rumah sakit maupun tuntutan dari keluarga pasien. Hal 
tersebut dapat menyebabkan terjadinya kesalahan yang

bisa membahayakan pasien. ${ }^{16}$

\section{KESIMPULAN}

Pada penelitian ini dapat disimpulkan dari beberapa variabel yang berhubungan dengan waktu tanggap adalah beban kerja $(p=0,004)$ dan masa kerja $(0,008)$, dimana faktor yang paling dominan berpengaruh dengan waktu tanggap yaitu beban kerja.

Berdasarkan kesimpulan diatas, maka untuk meningkatkan waktu tanggap cepat pada perawat di IGD RS. Medirossa Cikarang, maka peneliti merekomendasikan :

1. Bagi Manajemen Rumah Sakit Medirossa Cikarang, dapat meningkatkan mutu pelayanan yang cepat, dan mampu menyelamatkan pasien gawat darurat dengan mengadakan pelatihan, diskusi, workshop, dan pendampingan kepada perawat di IGD berupa konseling, serta mengoptimalkan tatanan ruangan IGD, melengkapi fasilitas dan sarana IGD, dan pemerataan beban kerja, sehingga dapat menyelamatkan pasien sesegera mungkin.

2. Bagi Perawat, diharapkan perawat dapat mempertahankan kinerjanya, bagi responden yang memiliki beban kerja tinggi dapat melakukan konseling, dan untuk perawat dengan kompetensi kurang dapat mengikuti pelatihan ataupun workshop mengenai kasuskasus yang jarang ditemui di IGD.

3. Bagi pendidikan, menambah wawasan kepada mahasiswa tentang penanganan pasien gawatdarurat dengan waktu tanggap

4. Bagi Peneliti Selanjutnya, menambah subjek penelitian, dan menambah variabel lain yang mempengaruhi waktu tanggap di IGD yang tidak diteliti di penelitian ini.

\section{DAFTAR PUSTAKA}

1. Gobel, Y., Wahidin, dan Muttaqin. Kualitas Pelayanan Kesehatan Instalasi Gawat darurat
Rumah Ssakit Umum Daerah Kota Makassar. Jurnal Administrasi Negara. 2018; 24(3): 177-188.

2. Muwardi. Materi Pelatihan PPGD. 2003. Surakarta.

3. Rahmanto, T.Y. Response Time Penanganan Sindroma Koroner Akut (SKA) di Instalasi Rawat Darurat RSU. Pandan Arang Boyolali Jawa Tengah. Berita Ilmu Keperawatan.

2014; 1(3).

4. Said, S., dan Mappanganro, A. Hubungan beban kerja Perawat Dengan Respon Time Pada Penanganan Pasien di Instalasi Gawat darurat Rumah Sakit Ibnu Sina Makassar. 2018; 3(1) : 71-81.

5. Sabriyati, W.N.I., Islam, A.A., dan Gaus, S. Faktor-faktor yang berhubungan dengan ketepatan waktu tanggap penanganan kasus pada response time 1 di Instalasi Gawat Darurat Bedah dan Non Bedah RSUP Dr. Wahidin Sudirohusodo. Universitas Unair Surabaya. 2012. Tersedia di : http://www.journal.faktor-

ketepatanwaktu.org.web.ref.html. Diakses pada tanggal : 25 Febuari 2021.

6. Wiyadi., dan Rahman, G. Analisis Faktor yang berhubungan dengan waktu tanggap Pada Pasien Gawat Darurat Di Instalasi Gawat Darurat (IGD) RSUD A. Wahab

Sjahranie Samarinda. 2020; 5(2): 78-84.

7. Ningsih, P., Wahid, A., dan Setiawan H. Beban Kerja Perawat dengan Waktu Tanggap Pelayanan Keperawatan

Berdasarkan Kategori Triage. Nerspedia. 2018; 1 : 20-27.

8. Puspitasari, D.I., Widjajanto, E., dan Rini, I.S. Hubungan Kompetensi Perawat Gawat Darurat Dengan Kinerja Perawat Di Instalasi Gawat Darurat (IGD) RSUD dr. H. Mohammad Anwar Sumenep Dan RSUD Sampang. Jurnal Kesehatan Wiraraja Medika. 2015; 5(2): 79-88.

9. Ayu, M.M. Pengaruh Kompetensi Dan Pelatihan Terhadap Kinerja Perawat Instalasi Gawat darurat Di RSU DR FL Tobing Kota Sibolga Tahun 2016. 2016. Tesis Fakultas Kesehatan Masyarakat Universitas Sumatera Utara. 
10. Junidar, S. Hubungan Beban Kerja Perawat Dengan Response time Pada Penanganan Pasien di IGD (Instalasi Gawat Darurat) RSUD Rantauprapat Tahun 2019. 2020. Skripsi. Fakultas Kesehatan Masyarakat Universitas Sumatera Utara.

11. Kambuaya, P.R., Kumaat, L.T., dan Onibala, F. Hubungan Beban Kerja Perawat dengan waktu Tanggap Pelayanan Keperawatan Gawat Darurat Menurut Persepsi Pasien di IGD RSUD Kabupaten Sorong. E-journal Keperawatan. 2016; 4(1): 1-9.

12. Asmawi., Hadju, A., dan Amiruddin, R. Pengaruh Kompetensi Terhadap Kinerja Perawat Instalasi Gawat darurat Dalam Melakukan Triase di RSUD kabupaten Majene. JST Kesehatan. 2017; 7(4): 389 394.

13. Kurniadi A. Manajemen Keperawatan Dan Prospektifnya. Teori, Konsep dan Aplikasi. 2013. Jakarta. Badan Penerbit FKUI.

14. Yudi, D., Tangka, J.W., Wowiling, F. Hubungan Beban Kerja Fisik dan mental Perawat dengan Penerapan Patient Safety di IGD dan ICU RSU GMIM Pancaran Kasih Manado. E-Journal Keperawatan. 2019; 7(1): 1-9.

15. Wiyadi., dan Rahman, G. Analisis Faktor yang berhubungan dengan waktu tanggap Pada Pasien Gawat Darurat Di Instalasi Gawat Darurat (IGD) RSUD A. Wahab

Sjahranie Samarinda. 2020; 5(2): 78-84.

16. Suryandari, D. Pengaruh Kompetensi, Motivasi, dan beban Kerja Terhadap Kinerja Perawat di IGD RSUD di Yogyakarta. 2018. Tesis. Program Studi Manajemen Rumah Sakit Unversitas Muhammadiyan Yogyakarta. 